International Journal of Finance and Accounting (IJFA)

BANKRUPTCY RISK INDICATORS AND FINANCIAL REPORTING TIMELINESS: THE CASE OF COMPANIES LISTED AT NAIROBI SECURITIES EXCHANGE, KENYA Isabella Kogei and Dr.Ambrose Jagongo 


\title{
BANKRUPTCY RISK INDICATORS AND FINANCIAL REPORTING TIMELINESS: THE CASE OF COMPANIES LISTED AT NAIROBI SECURITIES EXCHANGE, KENYA
}

\author{
${ }^{1 *}$ Isabella Kogei \\ PhD. Candidate: Department of Accounts and Finance, Kenyatta University \\ *Corresponding Author's E-mail: kogeiisabella@gmail.com \\ ${ }^{2}$ Dr.Ambrose Jagongo \\ Department of Accounts and Finance, Kenyatta University
}

\begin{abstract}
Purpose: The study sought to investigate effect of bankruptcy risk indicators on financial reporting timeliness of listed companies in Kenya.

Materials and Methods: The study adopted a desktop methodology. Desk research refers to secondary data or that which can be collected without fieldwork. Desk research is basically involved in collecting data from existing resources hence it is often considered a low cost technique as compared to field research, as the main cost is involved in executive's time, telephone charges and directories. Thus, the study relied on already published studies, reports and statistics. This secondary data was easily accessed through the online journals and library

Results: The results revealed that the studies done had conceptual framework gap. The study also found out that the study had geographical gap because they were not conducted in Kenya and also had different methodological gap.

Unique contribution to theory, practice and policy: The findings of the study add to the databank of knowledge on the effect of bankruptcy risk on the timeliness of financial reporting of listed on NSE which propels further discussion on the subject. The findings will provide useful insights to corporate executives on bankruptcy risk attributes that have a bearing on financial reporting for their implementation. The findings of the study inform investors on bankruptcy risk indicators to look into that contribute to timeliness of financial reporting. This information is very useful to investors when choosing in which listed companies to invest their money. Finally, the findings of the study inform the regulator (CMA) the timeliness of financial reporting of companies listed on NSE in Kenya. This information forms a base on policy formulation in search of measures that can protect and improve timely financial reporting in corporate world to enhance market efficiencies.
\end{abstract}

Keywords: Bankruptcy Risk Indicators, Financial Reporting Timeliness, Listed Companies 


\subsection{INTRODUCTION}

Financial Reporting is a standard accounting practice that uses financial statements to disclose a company's financial information and performance over a particular period. One of the financial information that is relevant and reliable is needed to create an efficient market that is timeliness, so that the timeliness is a necessity in the delivery of financial statements (Arifuddin et al., 2017). Financial Reporting has always been considered as the critical determinant for investment decision making of shareholders and other stakeholders of a firm (Yousuf, 2020). It provides information that is useful to investors, creditors and others in making investment, credit and similar resource allocation decisions. For instance, a positive financials report provides confidence to investors hence this influence moments of share price upwards, while a firm under financial distress will influence its share price to a downward trend hence resulting to low returns to investors (International Accounting Standards Board, 2018).

Timeliness is one of the qualitative attributes of useful information. The shorter the time between the end of the accounting year and publication date, the more beneficial the audited annual reports will be (Ohaka \& Akani, 2017). For decisions to be made efficiently and effectively, the investors, creditors and other interested parties should get the information on the financial statements on time as provided for by various jurisdictions such as Capital Markets Authority (CMA) for Kenyan case. Delays in financial reporting jeopardies the quality of financial information by not providing timely information to key stakeholders. In principle, it is argued that there is an inverse relationship between information value and the time taken to prepare financial statements, specifically the longer the time taken by the auditor to complete the audit, as reflected in the audit report lag, the stronger the signal to the market as there may be negative issues arising from the audit (Sultana, Singh \& Zahn , 2015).

Acknowledging the theoretical and practical importance of timely financial information to the decision-making process of capital market participants, regulators such as the Kenya Capital Markets Authority (CMA), established mandatory time periods within which firms are required to provide audited financial statements to shareholders and other key stakeholders via statutory filing requirements. The Fifth schedule of the Legal Notice No. 60 of $3^{\text {rd }}$ May, 2002 states, 'every issuer of securities to the public whether listed or not shall prepare an annual report containing audited annual financial statements within four months of the close of its financial year' (The Capital Markets Authority, 2002). A complete set of financial statements includes the balance sheet, income statement, cash flow statement, accounting policies, explanatory note and a statement showing either all changes in equity; or changes in equity other than those arising from capital transactions with owners and distributions to owners.

This study seeks to investigate the effect of bankruptcy risk on financial reporting of companies listed on Nairobi Securities Exchange, Kenya, while employing company size as the moderating variable.

\subsubsection{Financial Reporting Timeliness}

International Accounting Standards Board (2018) states that 'timeliness means having information available to decision-makers in time to be capable of influencing their decisions'. For instance, all Belgian firms have to file their financial statements, regardless of the format, no 


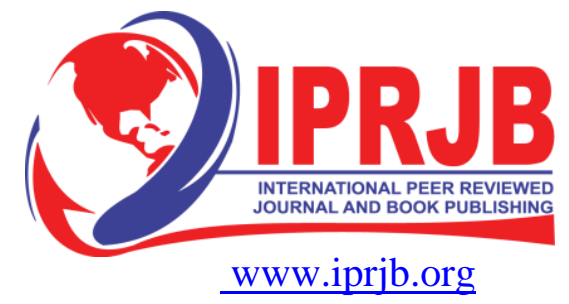

later than 1 month after approval by the annual meeting of shareholders, with a maximum of seven months after the closing date of the accounting year. If a firm file its financial statements late and third parties suffer a loss, the loss is assumed to result from the late filing unless proof to the contrary is provided. In other words, the onus of proof is reversed and lies with the firm filing its financial statements late. In addition, late filings are subject to administrative sanctions (Luypaert et al., 2016). Kenyan listed companies should prepare and publish annual audited financial statements four (4) months at the end of the financial year of the company (The Capital Markets (Securities) (Public Offers, Listing and Disclosures) Regulations., 2002).

The International Accounting Standards Board (IASB) is an independent, private-sector body that develops and approves International Financial Reporting Standards (IFRSs). International Accounting Standards (IAS) are older accounting standards issued by the IASB. The IAS were replaced in 2001 by IFRS. Globally, comparable accounting standards promote transparency, accountability, and efficiency in financial markets around the world. This enables investors and other market participants to make informed economic decisions about investment opportunities and risks and improves capital allocation. Universal standards also significantly reduce reporting and regulatory costs, especially for companies with international operations and subsidiaries in multiple countries.

IFRS set common rules so that financial statements can be consistent, transparent, and comparable around the world. They specify how companies must maintain and report their accounts, defining types of transactions, and other events with financial impact. IFRS were established to create a common accounting language so that businesses and their financial statements can be consistent and reliable from company to company and country to country.

In the Kenyan perspective, timeliness of audited financial statements is prescribed by the Company Act, 2015 as six months or approximately one hundred and eighty days. Furthermore, Kenyan banks are required to submit annual reports within three months or approximately ninety days from financial year end. Timely reporting serves to reduce unfavorable effects of moral hazard and the implications of adverse selection. Prior studies posit that delays in reporting present opportunities for insider trading and misappropriation or misapplication of corporate assets (Owino, 2017).

The primary role of financial statements is to report a company's financial information to internal and external users in a timely and reliable manner. Financial reporting is a link for communication to stakeholders and a basis for evaluation on performance or position of the company. The contents of financial reports are used as a basis to shape major decisions such as executive compensation, debt covenants, capital raising and making investment decisions (Hopkinson, 2017).

The IFRS adoption in Kenya was implemented in phases. Between 1973 \& 2000, the International Accounting Standards Committee introduced 41 bookkeeping principles. At the end of the period, the International Accounting Standards Board (IASB) replaced IASC. The incoming board was aimed at enhancing and filtering the accounting standards for a period of 8 years starting from 2000 to 2008 there was a significant reduction of the accounting standards from 41 standards to 28 by end of 2008. Primarily these standards are geared towards providing 


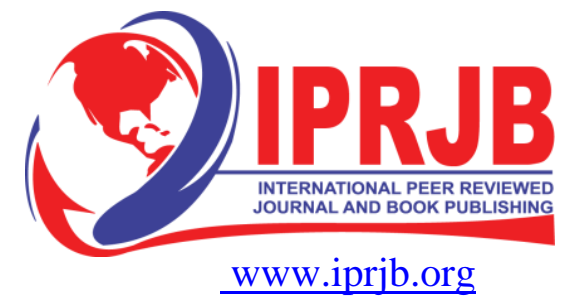

reliable, relevant, and timely for corporation investors and creditors in accordance to the IASB's accounting framework. It is a mandatory requirement for companies listed in the NSE to be IFRS compliant (Yousuf, 2020).

There is empirical evidence to demonstrate delays of firms in filing their financial statements. Luypaert, Van Caneghemand and van Uytbergen (2016) examined the financial statement filing lags among a sample of Belgian small firms. The results of this study indicated that around onethird of small firm financial statements are filed late (after the legal deadline), but that monetary sanctions could be an effective tool to encourage compliance with legal deadlines. Lambert, Jones, Brazel and Shiwalter (2017) asserted that the Securities and Exchange Commission filing deadlines increased time pressures for auditors of accelerated filers. As an apparent result, companies that were unprepared to meet these accelerated filing deadlines frequently filed their $10-\mathrm{K}$ 's late and experienced reductions in earnings quality.

Publication of financial statements affects the stock prices in the stock market. Too (2017), was a study done to establish if there is a relationship between the stock returns and the publication of the financial statements of listed commercial banks at NSE. Event study methodology was used to analyze stock returns to financial statement publication, event study enables determination of change of stock prices hence changes of returns by a particular change of event. An event period of 60 days was selected, 30 day prior to the announcement and 30 days after the announcement day was used to analyze the share prices movement during the period of announcement. The announcement day was represented by 0 . The data collected incorporated 7 listed commercial banks under a scope of 2 years (2015 and 2016). From the study findings, annual financial statements publication is a significant factor that influences the stock returns of listed commercial banks hence this event should be adopted by more companies to be listed at the NSE to better investors' returns. Reaction of investors behavior was observed through stock price movement before the announcement and goes on even after the publication of financial statements before the market stabilizes after a while.

\subsubsection{Bankruptcy Risk Indicators}

Bankruptcy refers to the situation in which the debtor company becomes unable to repay its debts reflected in terms of job losses, the destruction of assets, and in a low productivity (Aleksanyan \& Huiban, 2016). According to Horváthová and Mokrišová (2018), bankruptcy is a situation where the liabilities exceed the assets in the company, generally it happens due to under capitalization, not maintaining sufficient cash, sources are not utilized properly, management of activities is inefficient, sales decline, and market situation deteriorates.". It follows payment default or a situation in which the debtor company becomes unable to repay its debts. Bankruptcy is therefore, the risk that a firm will be unable to meet its debt obligations.

Bankruptcy risk is the whole spectrum of events and possibilities of business to experience financial distress which may or may not lead into bankruptcy filing. The risk of bankruptcy shows the possibility that a company will be unable to meet its debt obligations. Assessing of bankruptcy risk is important especially for investors in making equity or bond investment decisions, but also for managers in financial decision making of funding, investments and 
distribution policy. Failure prediction models are important tools also for bankers, rating agencies, and even distressed firms themselves (Altman et al., 2017)

Bankruptcy is a critical issue for firms due to its negative social and financial consequences. Risk information might not be fully disclosed in or understood from financial statements and, consequently, stakeholders' decisions may be inappropriate (Lukason \& Camacho-Miñano, 2019). Assessment and estimation of bankruptcy risk is important for managers in decision making for improving a firm's financial performance, but also important for investors that consider it prior to making investment decision in equity or bonds, creditors and company itself (Bărbuță-Mișu \& Madaleno, 2020).

A number of studies have been done to determine the extent of interconnections of a firms' reporting delays and bankruptcy risk. Prior literature shows that financially distressed companies could have incentives to hide the reasons why they are not performing well, hence delay their financial reports as illustrated by a number of studies below. Lukason and Camacho-Miñano (2019), a study aimed at investigating whether firms' reporting delays are interconnected with bankruptcy risk and its financial determinants. This study was based on 698,189 firm-year observations from Estonia. Annual report submission delay, either in a binary or ordinal form, was used as the dependent variable, while bankruptcy risk based on an international model or the financial ratios determining it were the independent variables. According to the study, firms with a higher risk of bankruptcy were more likely to delay the submission of their annual reports. Different stakeholders should be aware that when reporting delays occur, these can be conditioned by higher bankruptcy risk or poor performance, and thus, for instance, crediting such firms should be treated with caution. State institutions controlling timely submission should take strict(er) measures in cases of firms delaying for a lengthy period.

Lukason and Laitinen (2019) aimed to extract firm failure processes (FFPs) by using failure risk and rank the importance of failure risk contributors for different stages of FFPs. The dataset was composed of 1234 bankrupt firms from different European countries and three theoretically motivated FFPs were detected. For the dominant FFP found (73\% of cases), failure risk becomes high very shortly before bankruptcy is declared. Annual and accumulated profit- ability are the most important failure risk contributors for these stages of all FFPs, where failure probability exceeds 50\%. The obtained results provide important implications for bankruptcy prediction research and practice, especially in terms of identifying the most important financial predictors. Other similar studies include Adediran et al. (2019), Ferdayani et al. (2019), Savitri et al. (2019), Soewignyo and Wanda (2020), Wibowo and Saleh (2020).

A number of studies have concluded on various determinants of bankruptcy risks. In investigating the influence of Hofstede's original cultural dimensions on financial distress prediction, Laitinen an Suvas (2016), employed 1,255, 768 non failed and 22,594 failed yearly form observations from 26 European Countries to determine the most influential indicators of financial distress. Empirical findings showed that solvency and profitability are useful predictors of financial distress in international modelling. Bauweraerts (2016), a study done to predict bankruptcy in Belgian private firms between 2010 and 2014. The study concluded that firm age, firm size, profitability, liquidity and solvency do predict bankruptcy significantly. 
Bankrupt firms usually have liquidity problems (Lukason \& Laitinen, 2019). Ana, Vule and Maja (2020) is a study on the liquidity and Solvency of healthy and bankrupt entities in the Republic of Serbia based on 418 companies' financial statements of 2018. The study found that that almost $99 \%$ of the analyzed companies undergoing bankruptcy proceedings experience problems with liquidity and/or solvency. Consequently, the liquidity of the firm affects bankruptcy probability and empirical studies indicate that higher liquidity reduces the probability of failure.

The profitability is a significant indicator of failure for a number of years prior to the date of failure. (Altman, Iwanicz-Drozdowska, Laitenen and Suvas 2017; Lukason \& Laitinen, 2019). The annual profitability is relevant for bankruptcy prediction models as it "captures the capacity of the firm to manage its assets efficiently and generate enough funds to meet its financial obligations". In theory, an increase in profitability should reduce the likelihood of financial distress and failure (Chiaramonte \& Casu, 2017).

Rettobjaan (2020), This study aims to a study that aimed to analyze the Financial Ratio for Predicting Bankruptcy. The sample used in this study were SMEs according to PEFINDO25 period 2013 to 2017. The independent variables were liquidity, profitability, debt structure, solvency and activity ratio; and control variables were size and age, as well as the dependent variable is bankruptcy. Using logistic regression, the results of this research showed that liquidity, profitability and age has significant negative effect on bankruptcy. Debt structure has significant positive effect on bankruptcy. While solvency, activity ratio and size does not significantly effect on bankruptcy.

From the above illustration, liquidity, profitability and leverage form key determinants of bankruptcy risk. This study will therefore employ the three bankruptcy risk indicators to investigate their effect on financial reporting timeliness, while employing the firm size as the moderating variable in the effect of these bankruptcy risk indicators on financial reporting timeliness.

\subsubsection{Financial Reporting Timeliness of Companies Listed on Nairobi Securities Exchange}

The Companies Act (2012) governs the general framework for financial accounting and reporting and it lays down the minimum basic requirements for financial reporting. The Act requires companies to present accounts that show a true and fair view of its affairs. The Institute of Certified Public Accounts (ICPAK) is the body mandated to provide guidance on accounting and auditing standards. As from year 1999, Kenya adopted International Financial Reporting Standards (IFRS) through ICPAK and thus from year 2000 onwards, Kenyan companies are required to comply with IFRS. The Capital Markets (Securities) (Public Offers, Listing and Disclosures) Regulations (2002) within its fifth schedule (continuing obligations) requires listed companies to prepare annual reports containing audited financial statements within four months of close of financial year. The regulations further expound financial statements to include a balance sheet, income statement, statement of changes in equity, cash flow statement, and accounting policies and explanatory notes. Directors should select and apply accounting policies that are in compliant to International Accounting Standard (IAS). 
According to Gacheru (2018), there exist two aspects of financial reporting timeliness; first, the frequency of the interim reports, and second, the period between the fiscal year end and the annual report signing date. Globally, regulators have expressed concerns about both aspects of timeliness, but this paper focuses on the later because the Capital Markets' Authorities in East Africa require that only the annual reports be audited (The Capital Markets (Securities) (Public Offers, Listing and Disclosures) Regulations., 2002).

The number of companies listed on the NSE that have delayed in publishing financial statements has been on the rise. In 2020 alone, ten companies; Kenya Power \& Lighting Company, (KPLC), (Kenya Electricity Generating Company Ltd (KENGEN), Uchumi Supermarket Plc, Mumias Sugar Company, Kenya Re- Insurance Corporation, East Africa Cables, Crown Paints, Home Africa Plc, WPP Scan Group. In 2019, five companies; Uchumi Supermarkets Plc, KPLC, EAPCC and KENGEN. In 2017, 3 companies; Uchumi, Mumias Sugar and EAPCC.

Timely publishing of financial information by listed companies is one of the overriding determinants of stock price movement on the stock exchange and makes it possible for investors to evaluate the risk and expected returns of their stocks (Ohaka \& Akani, 2017). The International Financial Reporting Standards (IFRS) adoption of companies stated in Nairobi Securities Exchange assisted at reducing barriers to trading across borders of securities through making sure that the company accounts are easily reliable, transparent, and comparable (Yousuf, 2020). Delayed financial reporting allows investors with unusual detective abilities or wealth to acquire costly information. These "well-informed" investors trade on their private information at the expense of "less-informed" investors making policymakers voice concerns about the timeliness of public information disclosures (Sultana et al., 2015).

Several studies have examined the factors that influence timeliness of financial reporting. Studies such as (Abernathy et al., 2017; Owino, 2017) on Audit Report Lag (ARL) indicate that auditor related attributes, company related factors and corporate governance-related factors affect audit reporting timeliness. According to Abernathy et al, (2017), a study of the USA banking industry in 2014 by Alali and Elder revealed that company size, profitability, restatement of income, and abnormal audit fees were significant determinants of ARL.

Alfraih (2016), a study seeking to examine the influence of corporate governance mechanisms on audit delay in companies listed on the Kuwait Stock Exchange (KSE), concluded that there was a wide range in audit delay leading to delays in financial reporting among KSE companies, ranging from 7 to 159 days. After controlling for various company characteristics, there is a significant difference in the timeliness of audit reports depending on the combination of auditors: audit delay is significantly reduced when the audit is performed by Big- 4 companies. Moreover, companies with larger boards, a greater number of independent directors and separate CEOchairman roles are more likely to produce timely financial statements. Higher government ownership levels were associated with greater audit delay, while no significant association was found for institutional ownership.

Another study, Ohaka and Akani (2017) examined the relationship of firm size and board independence to the timeliness of financial reporting in companies quoted on the Nigerian Stock 


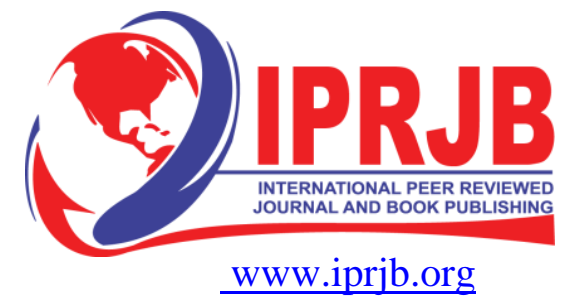

Exchange (NSE). Secondary data pertaining to the firms were derived from their annual reports and the NSE Fact Book for 12 years (2000-2011). The results established a significant relationship between firm size and timeliness of financial reporting; while in the case of board independence, the relationship was not significant.

Owino (2017) sought to investigate the determinants of Audit Report Lag (ARL) in companies listed in Kenya. A descriptive research design was used to study the auditor-related factors, company-specific factors and corporate governance factors affecting ARL. Two-stage panel least squares regressions were performed to establish the drivers of ARL. The study focused on a tenyear period from 2006 to 2015 . The findings revealed that auditor type was the most significant auditor related factor that was associated with ARL. In terms of company-specific factors, the return on assets (ROA) was significant and negatively associated with ARL. In terms of industry sector, the study found that listed companies in the banking sector had lower ARLs. Similarly, companies in the manufacturing sector had lower ARLs. The study found that listed companies in the investment sector had longer ARLs.

Gacheru (2018) concluded that the competence of the clients' finance team, completeness and quality of information provided to auditors and the type of the audit report (qualified or unqualified) highly influenced Audit Report Lag. Mathuva, Tauringana and Owino (2019), a study on Corporate governance and the timeliness of audited financial statements on listed Companies in Kenya, employed a set of 543 firm-year observations over the period 2007-2016. The findings of this study revealed that financial expertise in the audit committee, board size, board meetings and independence in the board are associated with longer ARDs. Overall, the authors find that the composite CG score has a positive influence on the timeliness of annual reports.

Borgi, Chardalou and Alzeer (2021) is a study done to examine the effect of some demographic characteristics of the Chief Executive Officer (CEO) on Financial Reporting Timeliness (FRT) in Saudi Arabia. The study sought test whether or not CEO characteristics, namely, tenure, accounting financial expertise, and sociability are associated with FRT. The sample of this study consists of 119 non-financial firms listed on Tadawul Stock Exchange for a period of four years (2014-2017). Employing panel regressions and two proxies of FRT, the findings report that a long-tenured CEO is associated with timely financial reports when the IFRS transition is simultaneously considered. The findings also concluded that CEO accounting financial expertise is significantly associated with timely financial reporting. The findings also report that CEO sociability is significantly associated with timely financial reporting in all instances.

The study will involve all the 64 companies that were listed as at December, 2020. The dependent variable is binary. Financial Reporting timeliness is a dichotomous variable coded with the value of 1 if the company delays in financial reporting based on the 4 months' time limit given by CMA, and 0 if otherwise.

\subsubsection{Nairobi Securities Exchange}

The Nairobi Securities Exchange (NSE), founded in 1954, has a six-decade heritage in listing equity and debt securities. NSE demutualized and self-listed in 2014. Its Board and management team are comprised of some of Africa's leading capital markets professionals, who are focused 


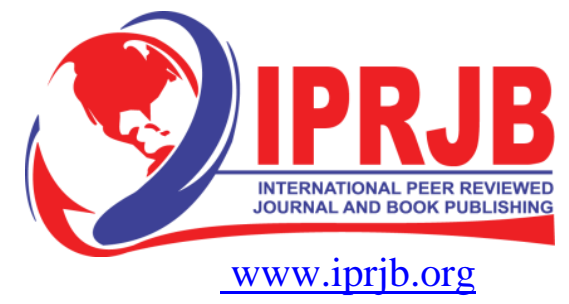

on innovation, diversification and operational excellence in the Exchange (Nairobi Securities Exchange, 2021). NSE operates under the jurisdiction of the Capital Markets Authority of Kenya. It is a full member of the World Federation of Exchange, a founder member of the African Securities Exchanges Association (ASEA) and the East African Securities Exchanges Association (EASEA). The NSE is a member of the Association of Futures Market and is a partner exchange in the United Nations-led SSE initiative.

According to (Yousuf, 2020), the Institute of Certified Public Accountants of Kenya (ICPAK) introduced the Financial Reporting Standards in 1998. This standard was to be operational for all financial statements' periods beginning 1st January 1999. Different governmental regulatory bodies such as Central Bank of Kenya (CBK) issues regulations that have incorporated the requirements on how to use IFRS. Other institutions issuing similar regulations includes; Insurance regulatory Authority of Kenya (IRA), Retirement Benefits Authority (RBA) and the Capital Markets Authority (CMA). Moreover, the NSE, on publication of company's rules, uses these accounting standards.

\subsection{Statement of the Problem}

A problem statement is a specific statement that clearly conveys the purpose of the research study and articulates the existence of the problem in a specific context (Mugenda \& Mugenda, 2019). From the foregoing literature, there is statistical and empirical evidence of delays in release of financial information through audited financial statements, leading to information asymmetry and stakeholders making investment and other decisions without the published financial information.

Statistically, a number of listed companies at NSE have had delays in preparing and publishing audited financial statements in Kenya. As per the foregoing literature, ten listed companies delayed in preparing and publishing their annual audited financial statements in year 2020 alone, as per the CMA regulations requiring publicly traded firms to prepare and publish their annual performance statements within four months after the close of the financial year.

A number of listed companies have been put under receivership have gone through mismanagement, corruption, bailouts by government or subsidizing on collapsing such as Uchumi, Mumias Sugar and Kenya Airways, National bank and Eveready (Kenya National Bureau of Statistics, 2017). The delay in releasing audit reports causes information asymmetry in the Kenyan market. An example is the case of Uchumi Supermarkets Limited which delayed in the release of its audit report for days causing her share price to fall from (Ksh 3.35) in September 2016 to (Ksh. 2.95) in May 2017 (Owino, 2017).

CMA Board took enforcement action for corporate governance and financial reporting failures and fraudulent schemes at the National Bank of Kenya (NBK) on April 4, 2018. The board took an administrative action against the NBK Board members and former Senior Managers who served at the Bank as at December 31, 2015 for the alleged misrepresentation of financial statements and embezzlement of funds at NBK. The Authority also recommended to the Office of the Director of Public Prosecutions, the prosecution of some of the senior managers and further criminal investigations of additional individuals. The Bank had published unaudited financial statements reporting profits of Kshs. 1.7 billion for the quarter ended 30 June 2015 and 
Kshs. 2.2 billion for the quarter ended 30 September 2015 but subsequently reported a loss of Kshs1. 2 Billion in its audited financial statements for the period ended December 31, 2015. (Capital Markets Authority, 2020).

Empirically, a number of studies have been done to determine the factors affecting this delay for example, (Alfraih, 2016; Borgi et al., 2021; (Dewi, Subekti \& Saraswati, 2019) Gacheru, 2018; Mathuva et al., 2019; Ohaka \& Akani, 2017; Owino, 2017). These studies were concluded on corporate Governance, firm size and Government ownership contributed to timely audited Financial Statements of listed companies. There is insufficient evidence to statistically determine the extent to which bankruptcy risk affects timeliness of audited financial statements of companies listed on Nairobi Securities Exchange, Kenya. This is another gap this study intends to fil.

Other studies have been done on companies listed on NSE but on other areas not on bankruptcy risk and financial reporting timelines, such as (Agustia, Muhammad \& Permatasan, 2020; Iyakaremye, 2015; Kinyua, Gakure, Gekara \& Orwa, 2015; Onsongo, Muathe \& Mwangi ,2020). The study therefore, seeks to investigate the effect of bankruptcy risk indicators on timeliness of financial reporting on companies listed on NSE, employing size as a moderating variable.

\subsection{Theoretical Review}

\section{Signaling Theory}

According to Owino (2017), signaling theory, developed by Spence (1973) states that corporate financial decisions are signals sent by the company's managers to Investors in order to shake up these asymmetries. These signals are the cornerstone of financial communications policy. Information asymmetry can be reduced if one party signals the other. Signaling is a reaction to information asymmetry in financial markets; in this case, companies have information that investors don't have. The signaling theory is mainly concerned with reducing information asymmetry between two parties.

Spence's (1973) seminal work on labor markets demonstrated how a job applicant might engage in behaviors to reduce information asymmetry that hampers the selection ability of prospective employers. Spence illustrated how high-quality prospective employees distinguish themselves from low-quality prospects via the costly signal of rigorous higher education. Spence (1973) utilized the labor market to model the signaling function $\mathrm{n}$ of education. Potential employers lack information about the quality of job candidates. The candidates, therefore, obtain education to signal their quality and reduce information asymmetries. This is presumably a reliable signal because lower quality candidates would not be able to withstand the rigors of higher education.

For the signaling effect to be successful, the news needs to be credible. If managers falsely try to signal news that they are of high quality when in fact they are of low quality and it is eventually revealed, subsequent financial reporting will not be viewed as credible. Companies that reports profits communicate to investors that they have a bright future ahead and are worth investing in. The timing of the release of audit reports may be viewed as a signal by investors of how the firm is performing. Early release of audit reports may be viewed as good news and may affect the 
firm's value positively. Late release of audit reports may be viewed as bad news and may negatively affect the firm's value (Owino, 2017).

According to Yousuf (2020), if there is an occurrence of signaling within a company, that would increase the earnings, but if it is revealed there were accounting errors, a product recall or a scandal, the earning would be adversely affected. Therefore, signaling could mean there will be higher earnings in the future or even higher stock price for a company.

The information signaling theory has informed the selection of board independence, leverage, complexity, firm size and profitability. Mukhtarudddin, Oktarina, Relasar and Abukosim (2015) examined the influence of firm size and complexity. The study found that firm size was significant. However, complexity was not significant leaving room for further studies on determinants of Audit Report Lag (ARL) in different countries and institutional set-up to investigate its influence on ARL.

(Owino (2017) investigated the determinants of Audit Report Lag (ARL) by listed companies in Kenya. The study concluded that profitability is the most significant company specific determinant of Audit Report Lag. Sunarto et al. (2020) concluded that large firms use reputable audit firms that they perform audits more efficiently so they will produce fairness information in their financial statements.

Dewi et al. (2019), while employing signaling theory, examined and analyzed the association between audit tenure and financial distress on delay in publication of financial statement in Indonesia. The study concluded that signalling theory will distinguish companies that provided good and timely information from those that do not have good news by infirming the market about their situation. Signals of good future performance provided by companies whose past financial performance is not good, will not be trusted by the market.

Savitri et al. (2019), a study on the influencing factors of the timeliness f financial reporting submissions on listed companies in Indonesia Stock Exchange in 2014-2016, employed profitability, leverage, firm size, outsider ownership and reputation of the public accounting firm as the independent variables. The study employed signaling theory. According to the study, Information asymmetry will occur if management does not fully convey all information that can affect the company's value to the capital market. To avoid asymmetric information, companies must provide information as a signal to investors. Asymmetrical information needs to be minimized, so public companies must give the company financial information in a transparent manner to investors.

Based on the signaling theory, companies that use accounting firms affiliated with the Big Four will make good financial statements and the fairness in their financial statements also will give a positive signal to the public. This is because accounting firm Big Four and accounting firms affiliated with Big Four are considered capable of doing their audit work more effectively and can be completed on time, so that the company will immediately submit its financial statements in a more timely manner.

The theory links to this study because financial reporting entails firms communicating to potential investors based on value and commitment signal, which reflects the value of the firm. 
International Journal of Finance and Accounting

ISSN 2513-4311X (online)

Vol.6 Issue 2, No.3. pp. 40 - 56, 2021

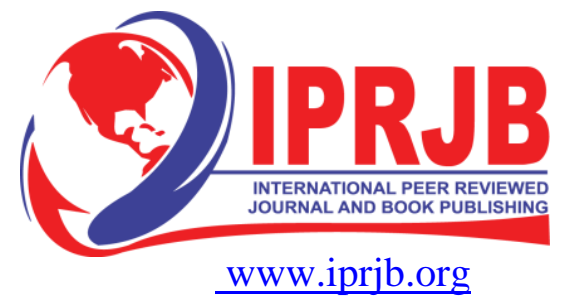

\subsection{Conceptual Framework}

The conceptual framework looked at the effects of liquidity risk management on financial performance of state owned enterprises and it is illustrated in Figure 1

\section{Figure: 1 Conceptual Framework}

Independent Variables Moderating Variable Dependent Variable

BANKRUPTCY RISK INDICATORS

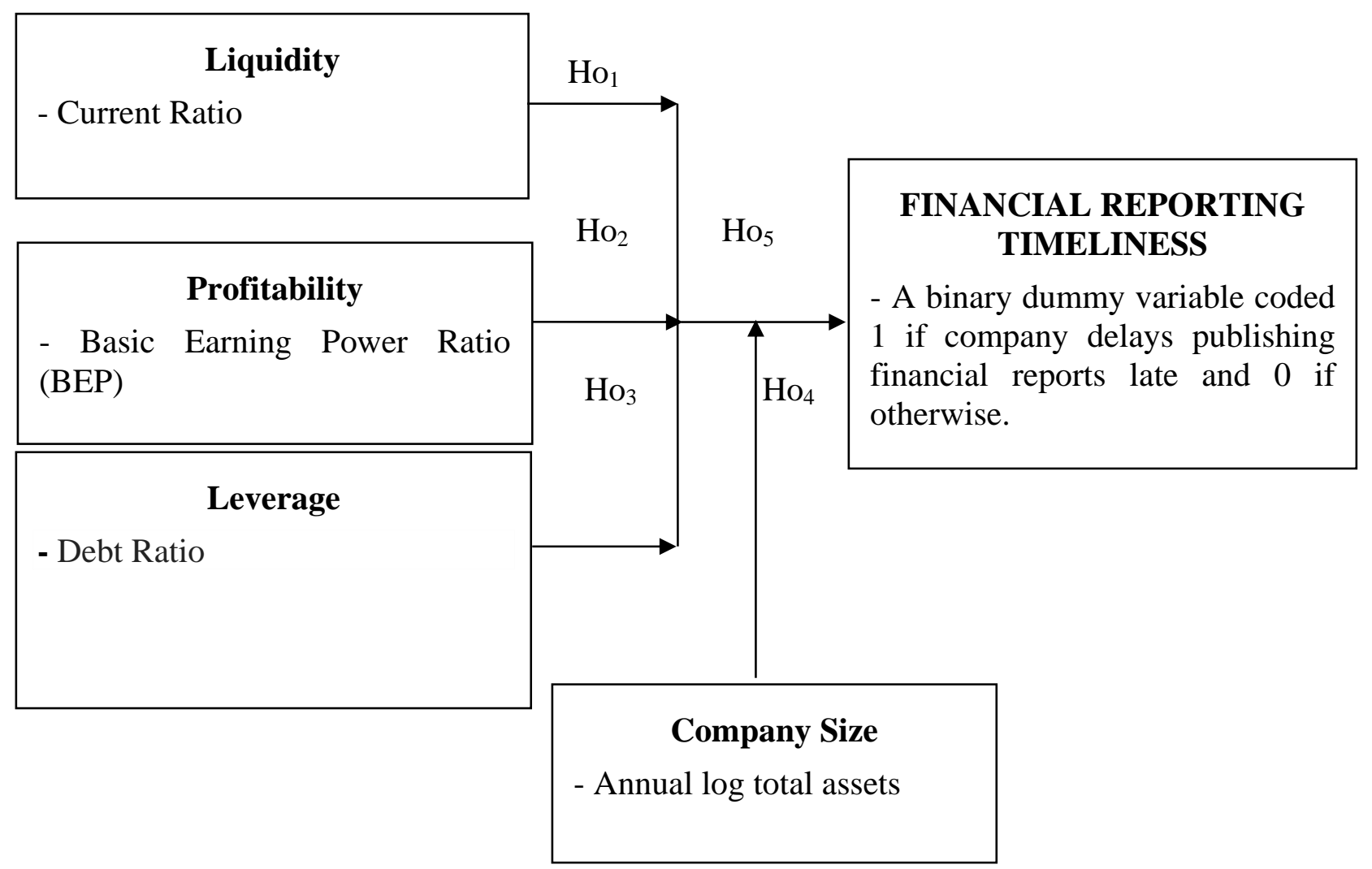

\subsection{METHODOLOGY}

The study adopted a desktop methodology. Desk research refers to secondary data or that which can be collected without fieldwork. Desk research is basically involved in collecting data from existing resources hence it is often considered a low cost technique as compared to field research, as the main cost is involved in executive's time, telephone charges and directories. Thus, the study relied on already published studies, reports and statistics. This secondary data was easily accessed through the online journals and library. 
International Journal of Finance and Accounting

ISSN 2513-4311X (online)

Vol.6 Issue 2, No.3. pp. 40 - 56, 2021

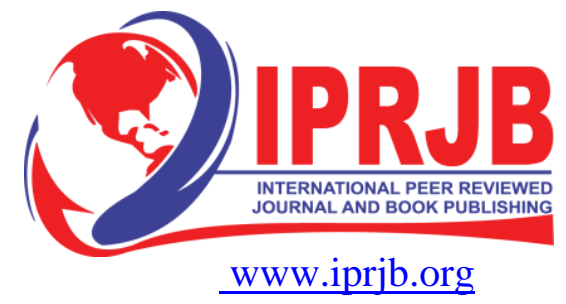

\subsection{RESULTS}

The results were grouped into various research gap categories namely as conceptual, methodological, contextual, and geographical.

\subsection{Conceptual Gaps}

Studies by Alfraih (2016); Ohaka and Akani (2017); Adediran et al., (2019); Borgi et al. (2021); Ferdayani et al., (2019); Dewi et al. ( 2019); Savitri et al. (2019); Sunarto et al., (2020); Wibowo and Saleh (2020); Borgi et al. (2021) had conceptual gaps. In addition, all the mentioned studies did not establish the effect of bankruptcy risk indicators on financial reporting timeliness of listed companies in Kenya. The studies did not outline the relationship between independent and dependent variable in a clear manner. Therefore the current study seeks to address these conceptual gaps.

\subsection{Contextual and Geographical Gap.}

Studies by Alfraih (2016); Ohaka and Akani (2017); Adediran et al., (2019); Borgi et al. (2021); Ferdayani et al., (2019); Dewi et al. ( 2019); Savitri et al. (2019); Sunarto et al., (2020); Wibowo and Saleh (2020); Borgi et al. (2021) had geographical gaps because they were not conducted in Kenya. This implies that the results may be inapplicable in Kenya since the social economic environment of Kenya and other countries differ. The current study seeks to address this gap.

\subsection{Methodological Gap}

Adediran et al., (2019); Ferdayani et al., (2019); Savitri et al. (2019); used Ordinary least square (OLS) multiple regression technique and Borgi et al. (2021) used panel regression. These regression methods differ with the proposed regression model in the study. The study will employ Logit regression and use dichotomous variable of timeliness of financial reporting as an indicator of timeliness instead of audit report lag. The current study seeks to address this methodological gap.

\section{CONCLUSIONS AND RECOMMENDATIONS}

The findings of the study will add to the databank of knowledge on the effect of bankruptcy risk on the timeliness of financial reporting of listed companies on NSE. The study will provide useful insights to corporate executives on bankruptcy risk attributes that have a bearing on financial reporting for their implementation. In addition, the findings of the study will inform investors on bankruptcy risk indicators to look into that contribute to timeliness of financial reporting. This information is very useful to investors when choosing in which listed companies to invest their money. Finally, the findings of the study will inform the regulator (CMA) on the timeliness of financial reporting of companies listed on NSE in Kenya.

\section{REFERENCES}

Abernathy, J. L., Barnes, M., Stefaniak, C., \& Weisbarth, A. (2017). An International Perspective on Audit Report Lag: A Synthesis of the Literature and Opportunities for Future Research. International Journal of Auditing, 21(1), 100-127. https://doi.org/10.1111/ijau.12083 
International Journal of Finance and Accounting

ISSN 2513-4311X (online)

Vol.6 Issue 2, No.3. pp. 40 - 56, 2021

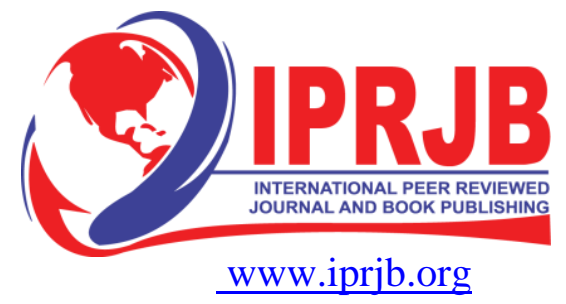

Adediran, S. A., Adejoh, E. O., \& Olubukola, S. (2019). Effect of Firms' Characteristics on Timeliness of Financial Reports of Quoted Insurance Companies in Nigeria. Research Journal of Finance and Accounting, 10(24). https://doi.org/10.7176/rjfa/10-24-06

Agustia, D., Muhammad, N. P. A., \& Permatasari, Y. (2020). Earnings management, business strategy, and bankruptcy risk: evidence from Indonesia. Heliyon, 6(2), e03317. https://doi.org/10.1016/j.heliyon.2020.e03317

Al-tahat, A. . (2015). Timeliness of Audited Financila Reports of Jordanian Listed Companies. International Journal of Management, 3(2), 39-47.

Aleksanyan, L., \& Huiban, J. (2016). Economic and financial determinants of firm bankruptcy: evidence from the French food industry. Review of Agricultural, Food and Environmental Studies, 89-108. https://doi.org/10.1007/s41130-016-0020-7

Alfraih, M. M. (2016). Corporate governance mechanisms and audit delay in a joint audit regulation. Journal of Financial Regulation and Compliance, 24(3), 292-316. https://doi.org/10.1108/JFRC-09-2015-0054

Altman, E. I., Iwanicz-Drozdowska, M., Laitinen, E. K., \& Suvas, A. (2017). Financial Distress Prediction in an International Context: A Review and Empirical Analysis of Altman's ZScore Model. Journal of International Financial Management and Accounting, 28(2), 131171. https://doi.org/10.1111/jifm.12053

Ana, O., Vule, M., \& Maja, O. (2020). Liquidity and solvency of healthy and bankrupt entities: Do financial statements show any differences? International Review, 3(4), 123-129. https://doi.org/10.5937/intrev2003123o

Aondona, A. P. (2016). Dividend pay-out policy determinants and their influence on manufacturing companies in Nigeria. The Certified National Accountant, 42(2), 9-21.

Arifuddin, Hanafi, K., \& Usman, A. (2017). Company size, profitability, and auditor opinion influence to audit report lag on registered manufacturing company in Indonesia stock exchange. International Journal of Applied Business and Economic Research, 15(19), 353367.

Bărbuță-Mișu, N., \& Madaleno, M. (2020). Assessment of Bankruptcy Risk of Large Companies: European Countries Evolution Analysis. Journal of Risk and Financial Management, 13(3), 58. https://doi.org/10.3390/jrfm13030058

Bauweraerts, J. (2016). Predicting Bankruptcy in Private Firms: Towards a Stepwise Regression Procedure. International Journal of Financial Research, 7(2), 147-153. https://doi.org/10.5430/ijfr.v7n2p147

Borgi, H., Ghardallou, W., \& Alzeer, M. (2021). The effect of CEO characteristics on financial reporting timeliness in Saudi Arabia. Accounting, 7(6), 1265-1274. https://doi.org/10.5267/j.ac.2021.4.013

The Capital Markets (Securities) (Public Offers, Listing and Disclosures) Regulations., 1 (2002).

Capital Markets Authority. (2020). Quarterly Statistical Bulletin (QSB) Issue 45/2020 (Issue 
International Journal of Finance and Accounting

ISSN 2513-4311X (online)

Vol.6 Issue 2, No.3. pp. 40 - 56, 2021

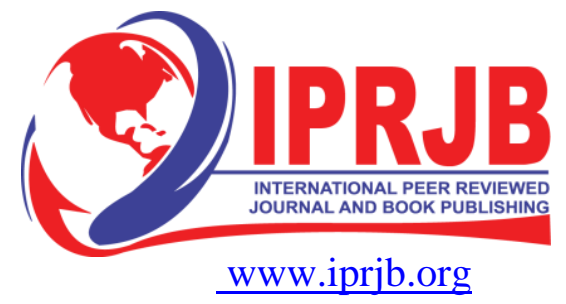

45/2020).

https://www.cma.or.ke/index.php?option=com_phocadownload\&view=category \&id=105:c apital-markets-quarterly-statistical-bulletin-2020\&Itemid=259

Chiaramonte, L., \& Casu, B. (2017). Capital and liquidity ratios and financial distress. Evidence from the European banking industry. British Accounting Review, 49(2), 138-161. https://doi.org/10.1016/j.bar.2016.04.001

Dewi, K. I. K., Subekti, I., \& Saraswati, E. (2019). The Determinants of Delay in Publication of Financial Statement. International Journal of Multicultural and Multireligious Understanding, 6(1), 9. https://doi.org/10.18415/ijmmu.v6i1.470

Ferdayani, E. N. P., Budiartha, K., \& Suprasto, H. B. (2019). The Capability of Tenure Audit as a Moderation in the Effect of Profitability, Financial Distress and Firm Size in Audits Delay. International Journal of Science and Research, 8(4), 630-635.

Gacheru, G. W. (2018). The Relevance of audit report lag and its corporate governance determinants among listed companies in the East African Community States. In Electronic Theses and Dissertations University Library. Strathmore University.

Hopkinson, N. M. (2017). Corporate Governance Practices and Quality of Financial Reporting of Companies Listed on Nairobi Securities Exchange in Kenya Ngalaka Muinde Hopkinson a Research Project Submitted To the School of Business in Partial Fulfilment for the Award of Degree in. Kenyatta University.

Horváthová, J., \& Mokrišová, M. (2018). Risk of bankruptcy, its determinants and models. Risks, 6(4). https://doi.org/10.3390/risks6040117

Imaniar, F. Q. (2016). Faktor-Faktor Yang Mempengaruhi Ketepatan Waktu Pelaporan Keuangan Perusahaan. Jurnal Ilmu Dan Riset Akuntansi, 5(6), 43-56.

International Accounting Standards Board. (2018). Conceptual Framework for Financial Reporting.

Iyakaremye, A. (2015). Analysis of Financila Perfoemnce and Financila Risk in Agricultural Companies Listed on the Nairobi Security Exchange. United States International University.

Kenya National Bureau of Statistics. (2017). Economic Survey.

Kinyua, J. K., Gakure, R., Gekara, M., \& Orwa, G. (2015). Effect Of Risk Management On The Financial Performance Of Companies Quoted In The Nairobi Securities Exchange. International Journal of Business \& Law Research, 3(4), 26-42.

Kinyua, S. M. (2020). Impact of Corporate Sustainability Reporting on Stock Returns of Firms Listed At the Nairobi Securities Exchange. In University of Nairobi. University of Nairobi.

Laitinen, E. K., \& Suvas, A. (2016). Financial distress prediction in an international context: Moderating effects of Hofstede's original cultural dimensions. Journal of Behavioral and Experimental Finance, 9, 98-118. https://doi.org/10.1016/j.jbef.2015.11.003

Lambert, T. A., Jones, K. L., Brazel, J. F., \& Showalter, D. S. (2017). Audit time pressure and earnings quality: An examination of accelerated filings. Accounting, Organizations and 
International Journal of Finance and Accounting

ISSN 2513-4311X (online)

Vol.6 Issue 2, No.3. pp. 40 - 56, 2021

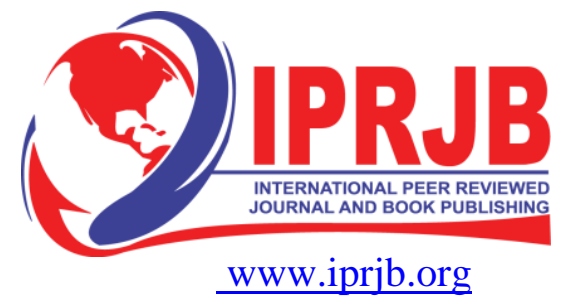

Society, 58, 50-66. https://doi.org/10.1016/j.aos.2017.03.003

Lukason, O., \& Camacho-Miñano, M. D. M. (2019). Bankruptcy risk, its financial determinants and reporting delays: Do managers have anything to hide? Risks, 7(3). https://doi.org/10.3390/risks7030077

Lukason, O., \& Laitinen, E. K. (2019). Firm failure processes and components of failure risk: An analysis of European bankrupt firms. Journal of Business Research, 98(June), 380-390. https://doi.org/10.1016/j.jbusres.2018.06.025

Luypaert, M., Van Caneghem, T., \& Van Uytbergen, S. (2016). Financial statement filing lags: An empirical analysis among small firms. International Small Business Journal: Researching Entrepreneurship, 34(4), 506-531. https://doi.org/10.1177/0266242615569324

Mathuva, D. M., Tauringana, V., \& Owino, F. J. O. (2019). Corporate governance and the timeliness of audited financial statements: The case of Kenyan listed firms. Journal of Accounting in Emerging Economies, 9(4), 473-501. https://doi.org/10.1108/JAEE-05-20180053

Mugenda, O. M., \& Mugenda, A. G. (2019). Research Methods: Quantitative, Qualitative \& Mixed Methods Approaches (K. P. Press (ed.)). Centre for Innovative Leadership and Governance.

Mugenda, O., \& Mugenda, A. G. (2019). Research Methods: Quantitative, Qualitative \& Mixed Methods Approaches (3rd ed.). Centre for Innovative Leadership and Governance.

Mukhtarudddin, M., Oktarina, R., Relasari, R., \& Abukosim, A. (2015). Firm and Auditor Characteristics, and Audit Report Lag in Manufacturing Companies Listed on Indonesia Stock Exchange during 2008-2012. Expert Journal of Business and Management, 3(1), 1326.

Nairobi Securities Exchange. (2021). About NSE. About Us. https://www.nse.co.ke/nse/historyof-nse.html

Odibi, I., Basit, A., \& Hassan, Z. (2015). Bankruptcy Prediction Using Altman Z-Score Model: a Case of Public Listed Manufacturing Companies in Malaysia. International Journal of Accounting and Business Management, 3(2), 178-186. https://doi.org/10.24924/ijabm/2015.11/v3.iss2/178.186

Ohaka, J., \& Akani, F. N. (2017). Timeliness and Relevance of Financial Reporting in Nigerian Quoted Firms. Management and Organizational Studies, 4(2), 55. https://doi.org/10.5430/mos.v4n2p55

Onsongo, S. K., Muathe, S. M. A., \& Mwangi, L. W. (2020). Financial risk and financial performance: evidence and insights from commercial and services listed companies in nairobi securities exchange, Kenya. International Journal of Financial Studies, 8(3), 1-15. https://doi.org/10.3390/ijfs8030051

Owino, F. J. O. (2017). The Drivers of audit report lag by listed companies in Kenya [Strathmore]. https://su-plus.strathmore.edu/handle/11071/5600 
International Journal of Finance and Accounting

ISSN 2513-4311X (online)

Vol.6 Issue 2, No.3. pp. 40 - 56, 2021

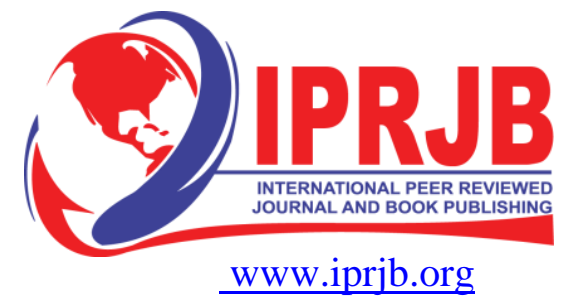

Companies Act, Pub. L. No. CAP 486, CAP 486 (2012).

Rettobjaan, V. F. C. (2020). Analysis of Financial Ratios for Predicting Bankruptcy in SMEs Listed on PEFINDO25. Journal of Management and Business, 19(2), 15-22. https://doi.org/10.24123/jmb.v19i2.466

Savitri, E., Andreas, \& Surya, R. A. S. (2019). Influencing Factors:The Timeliness of Financial Reporting Submissions. Business and Management Studies, 5(1), 43. https://doi.org/10.11114/bms.v5i1.4144

Soewignyo, F., \& Wanda, R. E. (2020). Audit Delay of Manufacturing Companies in Indonesia. Klabat Accounting Review, 1(2), 19-33.

Sufiyati, S. (2017). The Impact of Corporate Attributes on the Timeliness of Financial Reporting in Indonesia Stock Exchange. International Journal of Economic Perspectives, 11(1), 1720-1730.

https://search.proquest.com/docview/1964554467?accountid=10297\%0Ahttp://resolver.ebs cohost.com/openurl?ctx_ver=Z39.88-2004\&ctx_enc=info:ofi/enc:UTF-

8\&rfr_id=info:sid/ProQ\%3Aabiglobal\&rft_val_fmt=info:ofi/fmt:kev:mtx:journal\&rft.genre $=$ article\&rft.jtitle $=$ In

Sultana, N., Singh, H., \& Zahn, J. W. M. Van Der. (2015). Audit Committee Characteristics and Audit Report Lag. International Journal of Auditing. https://doi.org/10.1111/ijau.12033

Sunarto, S., AjiRamdhani, I., Oktaviani, R. M., \& Jaeni, J. (2020). Profitability, Liquidity, Size, Reputation of Public Accounting and Timeliness Reporting Financial Statement: An Analysis of Manufacturing Company Overview in Indonesia. Advances in Economics, Business and Management Research., 169, 419-423. https://doi.org/10.2991/aebmr.k.210311.084

Too, A. (2017). The effect of publication of financial statements on stock returns of commercial banks listed on the nairobi securities exchange. University of Nairobi.

the Effect of Company Profitability, Leverage , and Size on the Timeliness of Financial Reporting With Auditor ( Empirical Study on Food and Beverage Sub-Sector Companies Registered in Indonesia Stock Exchange 2017-2019), (2020).

Xiang, D., Worthington, A. C., \& Higgs, H. (2015). Discouraged finance seekers: An analysis of Australian small and medium-sized enterprises. International Small Business Journal, 33(7), 689-707. https://doi.org/10.1177/0266242613516138

Yousuf, M. A. (2020). The Relationship Between Financial Repoting Quality and Firm Value of Compnanies Listed at the Nairobi Securities Exchange (Issue November). University of Nairobi. 